Diasporic homecomings to the Kurdistan region of Iraq : Preand post-return experiences shaping motivations to re-return

\title{
Baser, Bahar
}

$2019-10$

Baser , B \& Toivanen , M 2019 , ' Diasporic homecomings to the Kurdistan region of Iraq :

Pre- and post-return experiences shaping motivations to re-return ', Ethnicities, vol. 19 , no.

5 , pp. 901-924 . https://doi.org/10.1177/1468796818757265

http://hdl.handle.net/10138/307609

https://doi.org/10.1177/1468796818757265

unspecified

acceptedVersion

Downloaded from Helda, University of Helsinki institutional repository.

This is an electronic reprint of the original article.

This reprint may differ from the original in pagination and typographic detail.

Please cite the original version. 
Diasporic homecomings to Kurdistan region of Iraq:

Pre- and post-return experiences shaping motivations to re-return

\title{
Dr Bahar Baser (Coventry University/ Stellenbosch University) \& Dr Mari Toivanen (University of Turku/University of Helsinki)
}

\begin{abstract}
This article examines the dynamics of voluntary return migration to the Kurdistan region of Iraq (KRI) in the post-Saddam period and provides a contextualized analysis of the returnees' experiences in a rapidly shifting geopolitical situation in Kurdistan. It specifically focuses on examining how diasporans' motivations to return, as well as their plans to re-return, are shaped in relation to their experiences in host societies and in the 'homeland'. Drawing from qualitative interviews, it shows that Kurdish diasporans' return can be characterized as 'diasporic homecoming' as it is motivated by the desire to contribute to the economic and political development of the KRI. However, the mismatch between expectations and 'homeland' realities combined with positive experiences and social capital accumulated in the host country makes plans for re-return more foreseeable and less risky.
\end{abstract}

\section{Keywords}

Return, re-return, diaspora, Kurdish, Iraq, homecoming, motivations

\section{Introduction}

This article examines the return migration to the Kurdistan Region of Iraq (KRI) in the 2000s. It sheds light on the returnees' motivations to return to Kurdistan in the post-Saddam era as 
well as on their pre- and post-return experiences and how those affect plans to re-return. Since the 1980s, the Iraqi Kurdish migration to Europe and North America has mainly been conflictgenerated due to experienced ethnic persecution and lack of human security in the context of war and political instability. After having formed vibrant diaspora communities, thousands of Kurds have returned temporarily or permanently to the region since the invasion of Iraq in 2003 by American-led forces and since the establishment of a semi-state structure in Kurdistan (Crowcroft, 2014; Paasche, 2016a; Voller, 2014). ${ }^{\mathrm{i}}$ The KRI has experienced a significant economic boom in the 2010s and the Kurdish Regional Government (KRG) has become a prominent actor in the Middle East since 2003 when the Ba'athist regime's reign terminated and Kurdish political actors replaced its political institutions (Aziz, 2011: 79). This has led to numerous diaspora members, who were forced to flee the region due to a series of genocidal campaigns (such as Al-Anfal), political instability and even war, to return to the region in the post-Saddam era (Paasche, 2016a; Voller, 2014).

However, the newly erupted war between the KRG and the so-called Islamic State (IS) has presented new dynamics for migration to and from the region. Thousands of young Kurds have left the region due to the ongoing conflict, which shows that, while diasporans are returning, many locals also dream of leaving Kurdistan (Mhamad 2015). The eventuality of an independent Kurdish state since the declaration of the de facto Kurdish state in 1991 seems to never have been as topical as it is now with the failing state of Iraq (Aziz, 2011; Bengio, 2012; Leezenberg, 2005). The KRG held a referendum for independence in September 2017, evoking reactions from its neighbors Turkey, Iran and Syria as well as from the central Iraqi government. This will surely affect KRG's political and economic situation in the long run, as independence claims might destabilize even further the political dynamics in the region (Kaya 
and Whiting, 2017). This also means that the voluntary return of diasporans, who have spent years outside Kurdistan might not be sustainable and permanent in the long run.

In this paper, we ask: What has motivated the return migration of Iraqi Kurdish diasporans to the KRI in the post-Saddam period? How do their pre-return experiences shape decisionmaking processes concerning return? And, how do both pre- and post-return experiences play into plans of a possible re-return? This study on Iraqi Kurdish return migration provides a compelling case for examining diaspora members' return to a post-conflict context that is highly volatile. It allows a shedding of light on the dynamics of return migration by examining what role pre-return experiences play in decisions to return, but also how they, together with post-return experiences, affect plans of eventual re-return. The article is based on fieldwork conducted in 2016. The material consists of qualitative, semi-structured interviews conducted with voluntary and non-assisted returnees to the KRI from 10 different host countries in Europe and North America. It provides insights to diasporans' motivations to return in a context of active nation-state building processes in the 'homeland', and on how their experiences both before and after return affect plans to stay or to re-return. The findings show that plans to opt for re-return to the host society were largely shaped by the mismatch between the expectations associated with a diasporic homecoming and the realities on the ground, with the latter being contrasted with positive experiences in the host countries. The following sections include a literature review on relevant empirical and theoretical studies on return migration, a section on methodology and the data-collection procedures and the analysis sections that present the central findings. The article ends with a discussion on the policy relevance of the findings.

\section{Return as diasporic homecoming}


Research on return migration has exponentially increased during the last decade or so, although certain sub-themes have drawn more attention than others, including the decision to return, post-return reintegration and reverse cultural shock (Carling et al., 2011). One of the major themes of interest in the return migration literature concerns the motivations for return migration, and in which cases the intentions to return concretize into an actual return to homeland (Carling et al., 2011; de Haas, 2005). Scholars have focused on factors such as age and generation (King and Christou, 2014), economic opportunities and investments (Tsuda, 2009a), family ties or other personal motivations (Emanuelsson, 2008; Jain, 2013) and transnational ties and engagements (Carling and Pettersen, 2014) to better understand the link between the possibilities and intentions of return and the actual return to the homeland. More recently, it has been posited that the impact of host society integration (de Haas and Fokkema, 2015; Di Saint Pierre et al., 2015), in other words the social and economic conditions in the host country, including discrimination, failed labor market integration and feelings of nonbelonging, might also motivate return migration.

Reasons to leave the 'homeland' can also play into motivations to return. Whereas the empirical research literature on return rarely distinguishes between that by labour migrants and that resulting of forced migration movements, we can say that the return dynamics are not similar to these two types of migration patterns. Although it is difficult to categorize return motivations to a post-conflict region in a clear-cut manner as different motivations often intertwine, Tsuda (2009a: 21) argues that, 'despite its fundamentally instrumental economic basis, diasporic return continues to be more ethnically driven and emotionally charged than other types of labour migration'. For instance, several case studies (Fehler, 2011; Gerhartz, 2010; Saar, 2017) show that identity-driven motivations and feelings of belonging to the 'homeland' play a role in return decisions in the first, but also in the second, generation. On the other hand, in the 
context of active nation-building, identity-driven or nationalist reasons to return to an ancestral 'homeland' can also play a major role in return decisions and desires to contribute to local development processes (Gerhartz, 2010). The motivations of voluntary return by forcibly displaced diasporans, as is the case with the Iraqi Kurdish diaspora, to a post-conflict society that is in the stage of active nation-building, remains largely understudied.

How can such 'ethnically driven and emotionally charged' return be better understood, without essentialising return as a mere reflection of lingering ethnic loyalties and yearnings? Markowitz and Stefanson (2004: 3-4) refer to 'homecomings', drawing from Brah's (1996) notion of the 'homing desire'. They suggest that return is not merely a nostalgic belonging to a homeland, to the past condition or a defensive response to the stigmatization in the host society, but that the return can become a project that opens doors to the future. However, the return is not always frictionless and the returnees can find themselves struggling with reintegration if realities on the ground drastically differ from their expectations. Besides host country experiences and how those are reflected in return decisions, more and more is known about returnees' individual experiences and the mismatch between their expectations and the realities they face in the homeland (Eriksson-Baaz, 2015: 24). As mentioned earlier, prior research has established that decisions to return can be shaped by expectations of what awaits in the 'homeland' as well as by diasporans' experiences of the host country. We suggest that pre-return experiences in the host country together with post-return experiences in the 'homeland' affect decisions to stay or, eventually, to re-return. This means that not only decisions concerning return, but also rereturn to host societies (or migration elsewhere), are shaped both by the realities in the homeland and prior experiences in the host society. Yet, relatively little is known of how host society experiences together with post-return experiences shape decisions to stay or to rereturn. 
What can then be considered as 'return'? As King and Christou (2011: 453) observe, there is a more 'variegated and nuanced exploration of the ontology of return, stretching its meaning across time, space and generations, and where the "place" of return and the type of movement can have various expressions_-real, virtual, imagined, desired, forced or denied'. We approach 'return' similarly to Long and Oxfeld (2004: 4), who understand it as ranging from short visits to more permanent repatriation, including temporary visits and preparations for return. This is different from 'return migration' that is accompanied with the intention of staying permanently, whereas 'return' can also be provisional and include short-term visits. Drawing from Long and Oxfeld's understanding of 'return', from Brah's (1996) understanding of diasporic, and Markowitz and Stefanson's understanding of 'homecoming', we approach the return of Iraqi Kurds to the KRI as diasporic homecoming. We understand diasporic homecomings as either a provisional or more permanent return that is, at least to some extent, motivated by feelings of returning 'home' and willingness to contribute towards it, but that is also informed by both pre-migration and pre-return experiences in the host society, and future-oriented with the possible idea of re-return, and so forth.

Theoretically, return migration has been approached within the paradigms of transnationalism, diaspora and mobilities (Cassarino, 2004) ${ }^{\mathrm{ii}}$. This paper draws from the transnational frame in the sense that it examines how decisions and motivations for return (and re-return) become formulated in relation to pre- and post-return experiences in both the national (host society, homeland) and transnational context. International migration has become more and more characterized by multi-sited transnational networks and mobilities, although scholars have acknowledged that the context in which the departure as well as the return take place is highly important (Tsuda, 2009a: 21). The transnational frame provides an analytical lens to recognize 
how returnees make decisions in the transnational space, but also how their (trans)national human and social capital (skills, networks, social resources) shape their decisions to return, and plans to re-return.

\section{Methodology}

As return migration is dynamic and complex by nature, qualitative approaches have become a preferred method in migration studies (Kunuroglu et al., 2017: 7). The primary data source for this paper consists of 26 semi-structured interviews conducted in three main provinces in the KRI, namely Erbil, Sulaymaniyah and Duhok, in early 2016. Furthermore, in this study we have solely focused on voluntary, non-assisted return, where the individuals have made the decision to return to the ancestral homeland without the existence of a threat of deportation or reasons for forced return.

The semi-structured interview guide was prepared by the authors and interviews were conducted, translated from Kurdish to English, as well as transcribed and anonymised by a research assistant. ${ }^{\mathrm{iii}}$ This data-collection method allowed the interviewees to narrate their own individual experiences (Kunuroglu et al., 2017: 7). The interview data were then coded by the authors, divided into empirical categories and re-grouped into themes, each of which is dedicated a separate analysis section.

[Table 1 about here]

The snowball sampling method was used in order to reach the interviewees. The authors and the research assistant used their previous contacts and pursued several leads so that the snowball sampling would not rely on only a few contacts. This data-collection strategy was chosen for a variety of reasons. Firstly, there is no official data on voluntary returns to the KRI 
and returnees are not easily identifiable via official records, making probability sampling unsuitable. There are also no phone or address books in the region via which we could have randomly contacted potential participants. Acknowledging its biases and limitations, we felt that the purposive snowballing method was the most suitable one as the returnees were otherwise hard to locate. Despite its limitations, we aimed at creating a sample that consists of interviewees with diverse backgrounds in order to have a broader idea of the dynamics surrounding return migration, including its challenges and realities. This strategy was pursued in three different districts also for the purposes of diversity in political views, since all districts have differing political profiles. As for the ethical considerations, names and any identifiable features of research participants have been anonymised. Each participant was given a consent form where they agreed to an interview that would be used for research purposes. The research assistant explained the aims of the project and received consent before he started the recording. Despite being assured of anonymity and careful processing of the data, some participants felt at unease and withdrew their consent during or after the interviews, probably due to the political climate in the KRI.

The interviews were conducted with returnees who had resided in the United States, Canada, Italy, Russia, Norway, Germany, Sweden, the United Kingdom, Denmark and the Netherlands at least for a decade prior to their return to the KRI. The participants were aged between 26 and 60 years old and they had left Kurdistan between 1975 and 2002. Some of the interviewees were children when their parents had left the region through either voluntary or involuntary migration. In this paper, we refer to them as the generation-in-between and approach their accounts under the category of 'ethnic return' suggested by Tsuda (2009a), referring to a 'return' to their region of ancestral origins. The total dataset consists of interviews conducted with 17 men and 9 women. We aimed to sustain a gender balance in terms of the number of 
participants, yet it was challenging to find female interviewees. Since our research assistant was male, the female participants might not have felt at ease when meeting with him one-onone in cafes or in their homes. Also, as Emanuelsson (2008) shows in her study on return migration to the KRI, it is often men who first return and bring in their families afterwards. Therefore, the higher proportion of male interviewees reflects most likely the gendered nature of return migration to the region. All interviewees were given a three-month deadline to withdraw their interviews if they wanted to. It was also most often female interviewees who withdrew their consent within the deadline.

We have conducted a thematic analysis (Tuomi and Sarajärvi, 2009) on the collected data and examined how the returnees narrated their experiences and motivations to leave and to return, and eventually to re-return in relation to their experiences in both the host society and the 'homeland'. In the first part, we discuss the forced displacement from the region, and the context of returning to a post-conflict society experiencing nation-building processes and economic prosperity. The second part deals with pre-return and post-return experiences, whereas the last section discusses the eventual aspirations to re-return in relation to the preceding sections.

\section{Diasporic homecomings to Kurdistan}

\section{Leaving the 'homeland'}

Current estimates of the Kurdish population originating mainly from Turkey, Syria, Iraq and Iran residing in Europe place the number of Kurdish speakers at between roughly 850,000 and 1.3 million, with the great majority living in Germany. Sizeable Kurdish communities also exist in the United Kingdom, France and the Nordic countries (Hassanpour and Mojab, 2005; 
Paasche, 2016a). The first wave of migration for Iraqi Kurds consisted in large part of highly educated middle-class men, who were politically active in their homeland and came from wealthy families. A small number of Kurdish intellectuals migrated for educational reasons prior to the 1970s, but the majority of the current Kurdish migration is conflict-generated. After the 1970 s, it was a variety of conflicts that drove Kurds away from their homeland. The $A l$ Anfal campaigns, targeting Kurdish villages and orchestrated by Saddam Hussein in the late 1980s, played an especially important role in generating migration from the region (Aziz, 2011: 12). Many Kurds were accepted as asylum seekers to different countries in Europe and beyond (Kinsley, 1991).

Irwani (2015: 42) states that it is impossible to find a single Kurdish family in the KRI who had not been affected by war and forced displacement. Indeed, most participants left KRI in the context of a politically unstable situation and insecurity. Only three interviewees mentioned economic reasons as their primary motivation to leave; yet such reasons were still linked to the political situation that had led to a lack of human security and an increased risk of ethnic persecution. The interviewees had varying social, economic and political backgrounds, and among them, some had been directly involved in political activities against the Saddam Hussein regime. As a result, their situation in the KRI grew gradually more challenging. However, interviewee accounts showed diversity rather than commonality concerning political reasons as motivations to leave. Some mentioned that their family members belonged to the Kurdish military forces (peshmerga), affiliated to either the Kurdish Democratic Party (KDP) or the Patriotic Union of Kurdistan (PUK), whereas others had no connection whatsoever to political movements. Furthermore, the decisions to leave contained a gendered dimension. Men had usually left alone, and only after having settled in the host country, they had invited their families to accompany them. With one exception, all female interviewees had left with their families. Indeed, the decisions to stay or to leave were mostly taken by men. As Binder and 
Tošić (2005: 617) note, gender plays an important role in decisions to leave, and can be closely connected to women's social positions as well as to the family constellation in conflictgenerated migration. In cases when the whole family left at the same time, it was usually via NGOs and international organizations which had guaranteed the safe travel and facilitated asylum application procedures in the host country.

Fleeing the country during wartime or in the midst of the on-going political crises was extremely hard, regardless of whether it was done via institutional channels (via NGOs, for instance) or in cases when the interviewees had used smugglers. Speaking of the related risks during the journey, some interviewees had been captured, arrested or detained before arriving in the host society. The popular routes were to cross the border to Turkey, then to find ways to Greece, and from there on to other European countries. Several struggled to collect the money necessary to complete the journey, but those who could save a sufficient amount, opted to use smugglers to get out of the conflict zone. Most usually had succeeded at the first attempt, but some could reach Europe only after the second or third attempt-delaying the inevitable departure instead of deterring it. However, social networks played a crucial role in two aspects. Some had reached the smugglers through friends and family networks, and relied on them to cover the costly journey. Migration routes were rarely straightforward and usually passed through several countries before the participants had reached the country of settlement, although a few arrived directly from Kurdistan. Those successful in crossing the Turkish-Iraqi border and being placed in a refugee camp in Turkey, would finally find a way to go to Canada, Australia or the United States via international organizations such as the UNHCR. The preexisting networks in the homeland were also employed in connection to diaspora networks in the host societies to reach the society of settlement. Individual networks seem to have been the most popular factor in terms of choosing the destination country; in cases such a choice was available. Relationships with homeland political parties had made it easier for the politically 
active interviewees to cross borders and utilize the transnational (diaspora) networks. On the other hand, already existing transnational networks, such as friends and family abroad, became facilitators during the departure process and enabled reaching (sometimes, although not always), desired destinations.

I was looking to go to England, but I didn't succeed. So I had a family member, who lives in Holland, and he said that Holland is okay. I had never heard about Holland before. I had only heard about the cheese and milk ... that was the only thing I knew about it.

Similar testimonies show that choices for the country of settlement were more or less involuntary. Some interviewees wished to go to a specific country, like the United Kingdom, but when they did not succeed due to economic or other reasons, they settled in another country. Testimonies also reveal that rumors circulating in the homeland had an impact on decisions about where to go. For instance, the Netherlands was known for its 'Kurdish-friendly' and generous asylum policy, hence it became a destination country for many.

\section{Returning to the 'homeland'}

The meaning of 'home-coming' was symbolically significant, since the departure had been involuntary in the context of forced displacement, whereas the return was voluntary. A majority of returnees identified the improved security situation as the main determinant for their return, explicitly referencing the fall of the Saddam Hussein regime in 2003, although they were also conscious of the growing political instability in the region. Indeed, the participants' reasons to return were most often related to what we have named 'diasporic homecoming', although such 
reasons were often intertwined with other motivations discussed later. We categorized return motivations that referred, on the one hand, to emotional attachments to Kurdistan as home, to Kurdish culture and language and to feelings of 'Kurdishness' and, on the other hand, to the desires to contribute to the region that had become possible in the context of the improved security situation. Ten interviewees listed these as a primary motivations for return and another 10 listed them as secondary reasons Although there was an overlap between these two motivations what could be categorized as 'cultural' and 'nationalist', in the first case the return was motivated by wanting to be with people who shared common values, language and culture, while in the other one, the stress was more on selfless motivations to answer to a 'homeland calling'. Four interviewees had returned, uniquely, because they wanted to 'serve' Kurdistan at this critical moment, and referred to altruistic and nationalist reasons for returning.

When you meet Kurds from Canada, USA and Europe, you see the desire that they want to come back and do something for Kurdistan. Because when we left, we knew that we have to come back. We cannot just leave it.

My motivation is to develop the industry in Kurdistan, to do something in Kurdistan to assist people and I think this is my biggest motivation.

Several returnees spoke of 'cultural' reasons together with an obligation to return to the homeland and to contribute to its prosperity. Some testimonies also showed that returnees came back with their political projects to contribute to transitional justice and commemoration in the KRI, and to serve as 'role models' for Kurdish society: 
I came here to teach, I was really excited about teaching. I wanted to build memorialization projects in Kurdistan, and to contribute to research and genocide awareness...

I said that as a Kurdish woman, I can do a little bit ... just put one stone in the wall of Kurdish improvement. It makes me happy and I think we all can have a small impact and in the end we will see some changes in the society. We will be role models, I hope.

The sense of duty and obligation to return 'home' and participate in the development of Kurdistan has also been identified within studies conducted on the Kurdish diasporas in different contexts, including on the second generation (Toivanen, 2014). Indeed, van Bruinessen (2000: 67) has examined the relationship between exile and Kurdish nationalism and stated that 'it was exile that transformed Kurdistan from a vaguely defined geographical entity into a political idea'. The decision concerning the diasporic homecoming, motivated by nationalist or culture-related reasons, takes place in the transnational, Kurdish diaspora space. However, how Kurdish diaspora members' sense of obligation to contribute to 'homeland' development concretizes into an actual return has remained understudied.

At times such culturalist and nationalist reasons become intertwined with economic motivations and business opportunities present in the region. The return migration of the Iraqi Kurdish diasporans in the post-Saddam period needs to be situated both in the context of active nation-building processes but also in the context of economic development in the KRI. Economic reasons were given as the second most important motivation: seven participants claimed that they returned for better economic conditions in the KRI or that they had found a 
better job than the one they had in the host society. For instance, some interviewees said that they found a job before they returned or that they easily found one right after their arrival. Family connections, previous social networks and their newly acquired skills played a role in this. Therefore, the diasporic homecoming took place in the context of the economic boom, the rising political economy of the region and with the possibility of contributing to and prospering in the KRI.

Indeed, the Iraqi Kurdish region experienced rapid economic growth in the post-Saddam period, partially in the form of foreign investments, which led to a political stability without comparison elsewhere in Iraq. To return and to participate in the development of Kurdistan had become possible after the fall of the Saddam Hussein's regime in 2003. As Eriksson Baaz (2015: 23) argues, return is also about giving back, which means using the knowledge acquired in exile to contribute to the development of a post-conflict homeland. The return was narrated with a consciousness of the social and human capital the returnees brought with them: the interviewees' motivations for returning were informed by the eventuality of being able to contribute and make an impact in homeland development through the accumulated social capital from the host societies that could be put to good use in the reconstruction of the Kurdish post-conflict society and, eventually, to gain economic benefits.

Lastly, family-related reasons played a significant role in decisions to return. Five interviewees mentioned that they returned due to family reasons: their elderly parents needed care and since they could not migrate, their children had chosen to return to care for them. This was also seen as a cultural characteristic, and therefore a duty. For a few, marriage was a motivation to return and very few also mentioned that they had had to return with their parents, who had made the decision. The importance of family and relatives as a primary motivation for return has been 
shown in previous research on conflict-generated migration (Fleisher, 2008). Only one participant recounted the 'need for change' and desire for 'adventure' as the main motivation to return, whereas the overall material provided little evidence of lifestyle-motivated migration more commonly associated with labor-migration-generated diasporas.

The interviewees of this study narrated their motivations to return in relation to the stark contrast that existed between the involuntariness of their departure and the voluntariness and freedom to return. Indeed, the experience of involuntary migration and the context in which it had taken place (forced displacement in the context of conflict and war) was inseparable from the experienced freedom of mobility manifesting in voluntary return (to the context of a relatively peaceful and prosperous, nation-building society). This study shows that such dynamics of departure and return play a significant role in shaping return decisions and ought not be dealt with separately. In addition, host society experiences together with post-return experiences are also essential in determining whether returnees opt to stay or to leave again.

\section{Everyday experiences before and after return}

\section{Away from 'home': Positive host country experiences}

Different from the experiences of economic migrants, Di Saint Pierre et al. (2015: 1837) observe that refugees' migration history is 'peculiar since many of them might not have planned to migrate but had to leave their country due to force majeure'. This may not only shape the reasons to return, but also their experiences in the new society of settlement. More than half of the interviewees recounted that their first impressions in the host country right after arrival had been a cultural shock and language problems, but also reported feelings of 
strangeness and loneliness that persisted during the first months. Several had also felt 'free', 'impressed' and certain that they had made the 'right decision'. One major issue determining their general well-being was the receipt of asylum status and welfare benefits. On the other hand, participants, who had spent a considerable time at a refugee camp, struggled and depicted their situation in more negative terms compared to those who had not stayed in refugee camps. The traumas of the conflict clung to the interviewees for a long time:

I was shocked, I couldn't compare the place I lived in with the new place, which was clean, and where there were flowers in the streets. In the place where I used to live in there were daily bombings by Saddam, and because of the sounds of bullets I couldn't sleep. In Germany, I would ask myself at night 'why there are no sounds [of war]'?

While the legacies of war lingered in their memories and were visible in their accounts, the participants had evaluated their new situation as an act of fleeing from the war. While acknowledging that hardships were merely a part of a transition period, some got used to the new environment more easily than others, namely those interviewees who had arrived while fairly young to the country of settlement. The generation-in-between interviewees acknowledged the advantage of arriving young, compared to their parents, who struggled considerably. Similar to previous literature on the Kurdish generation-in-between (Toivanen, 2014), the interviewees felt more 'at home' in the society of settlement compared to their parents.

Having gotten there at a very young age, we integrated very quickly, me, my sister and brother. So our culture and our norms and values were more Dutch or English 
than Kurdish, because we arrived there at such a young age. It took a long time for my parents to let go of the Kurdishness.

First-generation participants also felt this divide between them and their children, and one interviewee even mentioned that his biggest fear had been 'losing Kurdish culture' in the host society. For this reason, he and his family had attempted to strengthen ties with their contacts back in Kurdistan, but had also taken measures by sending their children to a Kurdish language course in order to facilitate their adaptation in case of return.

It is noteworthy that the overall experiences across the host societies were positive, especially for those settled in the United States, Canada and Sweden. Di Saint Pierre et al. (2015: 1838) suggest that the social and cultural isolation in the host country foster return decisions. Contrary to this, the majority of participants finally returned due to other reasons than negative experiences in the host society. Only a few interviewees mentioned that they or their family members had experienced discrimination in the context of rising xenophobia after 9/11 (see Bolognani and Erdal, 2017). There were also conflictual inter-ethnic relations in the host society:

I haven't experienced discrimination but my parents have ... based on their religion, and especially after $9 / 11$. For me, the discrimination was based on being a Kurd, but it was not by Canadians, but by Arabs and some other groups.

I haven't experienced it personally, but my mom, she used to wear a scarf and I remember that she received comments about her scarf quite a few times. They told her go back to her country in Holland. 
The rise of xenophobia in the post-9/11 era was reflected in interviewees' experiences in the host countries, yet such negative experiences were not listed as motivating factors to return. Whereas earlier hypotheses on return migration associate it with failed integration, more recently scholars have shown that the relationship is not that clear-cut. For instance, Fokkema and de Haas (2015) examine the relationship between positive integration and negative return intentions in their study on four migrant groups from Africa in Spain and Italy. They show that structural integration ('employment, housing, education, political, and citizenship rights') generally has a negative effect on return intentions. However, when looking at particular indicators more specifically, they notice that education has positive effect on return intentions, therefore countering the more assimilationist and neoclassical interpretations according to which negative integration would lead to return migration.

This was also the case for Iraqi Kurdish returnees, who defined themselves as "wellintegrated' ${ }^{\text {iv }}$ Whereas the lack of language skills and integration in the labor market had delayed their adaptation to the host country in the earliest stages of settlement, their situation had improved with time. After the first cultural shock and struggles to adapt, the interviewees listed several benefits in their host societies, including education, employment, health care, rule of law, justice and human rights, and the overall human security in the countries of settlement. Furthermore, many expressed feelings of gratitude to the host societies that had provided them with welfare services and opportunities:

I felt safe and free. You can say anything you want. Do anything you want. [The Netherlands] 
They treated me well in two years and I am thankful to German people who returned me to life.

Indeed, more than half of the interviewees acquired significant human capital abroad, including high school diplomas as well as $\mathrm{BA}, \mathrm{MA}$ and $\mathrm{PhD}$ degrees in engineering, philosophy, linguistics, management, medicine and law. Only one interviewee mentioned that he could not get into a program, while three others said they were not interested in acquiring degrees. As Van Houte (2014: 566) rightly suggests, not all migrants benefit from their migration experience in these terms. However, some participants had already started from a privileged position and managed to accumulate more social capital in the host society, whereas others struggled more. As Tsuda (2009b: 228) states, 'it is a combination of external host society reception and the human and social capital that immigrants possess that determines their socioeconomic success and integration'. However, accounting for the relatively high number of well-educated returnees in the sample, it seems that the human and social capital that has been acquired in the host societies has also enabled return (Fokkema and de Haas, 2015). A majority of the interviewees felt that successful integration actually played a facilitating factor to return to Kurdistan as not only the return, but also the re-return, were considered less risky due to their accumulated social and human capital.

Other major facilitating factors for return were the transnational networks and contacts with Kurdistan (Carling and Erdal, 2014). Very few participants were active in diaspora organizations, and had kept ties to homeland Kurdish political parties. One had chaired a diaspora organization; another one had founded various Kurdish NGOs in different European cities, and the rest occasionally attended protests and seminars organized by diaspora organizations. However, they had maintained fewer political transnational ties to Kurdistan 
when in the host societies, while sending economic remittances or maintaining frequent contact with family members and relatives. Conway et al. (2009) have argued, in the case of Trinidadian returnees, that repetitive visiting plays a role in decision to return. A majority of the interviewees also stated that they started visiting the KRI more frequently in the post-2003 era despite the sectarian violence that characterized the rest of Iraq.

Carling and Pettersen (2014) have presented a conceptual framework to better understand the triangular relationship between integration, transnationalism and return migration. Based on their study on 10 major migrant groups in Norway, their analysis shows that migrants with strong transnational ties and weak socio-cultural integration have the strongest motivations to return, but that it is the relative strength of integration and transnationalism that bears upon motivations to return. In other words, people who are strongly integrated and have strong transnational ties are as equally likely to return as people who are weakly integrated and have weak transnational ties. In this study, the interviewees' self-reported high levels of integration together with strong transnational ties seem to support Carling and Pettersen's (2014) hypothesis. As we will show later, this can also play a role in plans to re-return. Overall, whereas the involuntary departure became contrasted with voluntary return, also the positive host society experiences quickly became contrasted with challenges that the returnees encountered in the KRI.

\section{Challenges of 'diasporic homecomings'}

Van Meeteren et al. (2014: 336) posit that post-return experiences are shaped by returnees' 'human capital, transnational contacts, social networks, socio-economic integration in the destination country, legal status, and gender' (see also Cassarino, 2004). They also call for a 
contextualized theory and analysis on post-return experiences. We agree with the authors and suggest that, besides taking into consideration the societal or political context in which the return takes place, both pre-return and post-return experiences play a role in determining whether diasporans opt to re-return or stay in the 'homeland'. Whereas reuniting with relatives left behind and resettling in a familiar cultural environment were mentioned as the main benefits of return, a majority of interviewees mentioned that they had felt 'disappointed', 'disillusioned' or 'sad' after returning. The level of disappointment also needs to be understood in relation to returnees' expectations related to diasporic homecoming and to their motivations to contribute to homeland development. They felt that Kurdistan was missing the opportunity to become a democratic country in the Middle East and not using its full potential despite having the economic means to do so. Some returnees decided to return after having heard positive things from friends, family and acquaintances, but were now disappointed with the current situation in Kurdistan:

I was sad because the Kurdish TV channels lied to us. They show us just the beautiful views of Kurdistan.

I am so happy to see my family but the situation in Kurdistan disappointed me. [...] Life is more difficult than in the UK. There is no rule of law but a high level of corruption.

Several empirical studies point towards returnees' negative experiences with corruption and local power relations, feelings of frustration and disappointment in the homeland context (Emanuelsson, 2008). This is also the case with Iraqi Kurdish return migration, as shown by Emanuelsson (2008) and more recently by Paasche (2016a, 2016b). For instance, Paasche 
(2016b: 129) has found that, in many returnee narratives, KRG's ruling elites appeared as above the rule of law and ruling the region through neo-patrimonial patronage. He also suggests that returnees compare their return experience to pre-return experiences in the host countries' political spheres that they perceive as relatively more transparent and free. As he puts it: 'Exposure to a different political model abroad is seen as fomenting discontent with governance in Iraqi Kurdistan' (Paasche, 2016b: 129). The comparison between the KRI and the host countries, including freedom of speech, had led to further disappointment.

Indeed, corruption, political instability, endurance of the tribal system and nepotism were also mentioned as the main sources of disappointment among the interviewees of this study. Tsuda (2009b: 253) is right to suggest that it could be the same homeland but the "ethnic homecomings' may differ according to class, gender, status, and social capital among other things. Some found it hard to find employment to their liking without local forms of social capital, networks and connections. The lack of local forms of social capital were manifest particularly in the form of having the 'right' political networks and affiliations, and belonging to a family that supported a specific political party. A returnee from the education sector stated the following:

The challenge is that in the Ministry [of Education], they do not give me a job, they just give it to party members. And I am afraid of being fired from my job because I criticize the political parties too much.

There are too many obstacles. People need to depend on their connections and most things are based on where you have relatives. 
Some others admitted that they are having 'moral dilemmas' in terms of adapting to the homeland culture after so many years. Their 'Western' lifestyle included certain aspects such as respecting the rule of law, transparency in terms of governance as well as equality of opportunities. Indeed, the 'home-comers' are not always welcomed by the local population that stayed behind. The relations between the locals and the returnees might become tense especially if they are perceived as outsiders (Åkesson and Eriksson Baaz, 2015: 10). The KRI was not considered to offer an enabling environment, and several participants complained that their efforts were looked down on, if not suppressed, by the locals. During the first few years of return there was little contact with the locals. Some interviewees did not define their contacts with the local population as conflictual, but admitted that there was isolation: they did not mix much and had their own social spaces. However, some did mention perceived discrimination and hostile behavior. Two interviewees specifically mentioned that they had been accused of fleeing the country when the situation had been bad and that they had returned when this had changed. One interviewee who had recently returned from Germany said that he was perceived as a 'traitor' because he had left when 'Kurdistan needed him the most'. Another interviewee from the USA testified that some locals had told her that "now that Kurdistan has money, you are coming back from USA and Europe'. Half of the interviewees had had no tensions with the locals. Although agreeing upon the potential of returnees to make significant economic and political contributions, half of the returnees had experienced that the locals saw them as a threat to their jobs and status and considered their interventions and education too 'Western', ‘foreign' or ‘superior'. For example, one returnee had pursued his career as a university lecturer in the KRI, but felt that the work ethics were too different: 
In the first two years of my employment, I was working in Denmark. Therefore, there were tensions sometimes and some professors tried to sack me. Even outside [the] work place, I had tensions with other people.

Female interviewees recounted that they had experienced more open and freer gender relations in their host countries, thus leading to more problems to adapt compared to their male counterparts (see Emanuelsson, 2008; Grabska, 2015: 139). As one stated: 'It is just a country for men here, not for women'. She reflected on her life in the United Kingdom in comparison with her recent experience in the KRI:

I've lived my whole life in there [England] so I have many positive and negative experiences in my life. So coming to Kurdistan I realized that it was a positive experience because first of all as a girl ... as a single woman you are free. You are free to do what you want and where you want to go ... so there is nobody who tells you don't go out, don't work or get married. You know there is no pressure over there, there is no pressure when it comes to social issues. I just feel that women there are more independent, they are encouraged to be independent, they are encouraged to work, to make their own living, not to care about what people say about them ... or whether they get married or not.

Another interviewee also reported that:

One day I was wearing a short skirt and the taxi driver told me he would not pick me up. For women it is difficult to live here ... My plan was [upon return] to work with gender equality and to motivate women to be as free as men. I worked for that ... but the government did not respond. It did not support the plan. 
In the majority of accounts, not all interviewees had experienced disappointment and disillusionment upon return. Some contrasted the prevailing realities in Kurdistan with the situation under the Ba'ath regime where there was the constant fear of extinction. In such accounts, nationalist feelings and emotional attachments seemed to prevail over the political and economic expectations. However, the current war against IS and the international conundrum also made them feel insecure in the KRI, especially since after their return, the situation had rapidly deteriorated alongside with the economic situation.

Drawing from the transnational frame, Van Houte and Davids (2008: 1411) emphasize 'the importance of defining sustainability of return through the use of the concept of mixed embeddedness, and the different factors that influence this embeddedness'. They understand the term 'embeddedness' in terms of an individual finding his/her position in the society and feeling a sense of belonging within that society, whether it is in form of economic (sustainable livelihood), social (acceptance and networks) or psychosocial embeddedness (identity), or all these. In this way, they link migrants' experiences in the host society to the everyday epistemologies of returnees in the post-return context. Similarly in this case, the everyday epistemologies prior to departure (the context of forced migration), after the departure and settlement in a host society (with positive experiences) and after the diasporic homecoming (with a mismatch between expectations and realities) altogether shaped returnees' reflections on whether to stay or to leave again. Such reflections on return as well as on re-return also contain a gendered and generational dimension, in the sense that pre-return and post-return experiences can be quite different for men and women, for first-generation migrants and their descendants, and intersectionally so. 


\section{Reflecting on the re-return}

Diasporas are often treated as agents of development and peace-building, and some states are known to have drafted specific diaspora strategies and ministries to attract the diasporic return (Ho and Boyle, 2015). However, whether the home country creates an enabling environment (Brinkerhoff, 2012) for such interventions is the key to understand the dynamics of 'diasporic homecomings' and the eventual contributions it can generate. Although the KRG officials repeatedly welcome the return of diaspora Kurds, the general conception among the returnees was that the KRG was not able to create an enabling environment for them to contribute to the development of Kurdistan. All the interviewees, without exception, stated that the KRG had no policies for welcoming or even encouraging diaspora members to return. Local forms of (family) networks and social capital seemed to play a huge role when it came to turning the return experience into a 'success story', especially in the realm of investment and political positions. As mentioned by Åkesson and Eriksson Baaz (2015: 3), 'successful return migration is not primarily dependent on the various forms of social, cultural and economic capital obtained abroad, but on the various obstacles posed by the structures encountered upon return and the returnees' ability to transform the migrant capital they have attained'.

A majority of the interviewees' accounts reflected that the return was not considered as a permanent, one-way move to the 'homeland', but that it was an on-going, open project leaning towards the future, and one that would eventually involve continuous transnational circulation (see Eastmond, 2006). Concerning the possibility for re-return to the host country, 11 interviewees out of 26 mentioned that they were planning to move back within a short time period, and six had settled in Kurdistan permanently. Among them, some found it difficult to move again due to old age or because they were married to somebody local. One interviewee 
mentioned how hard the situation was for her children in Kurdistan. Despite being aware of the challenges she might encounter as a woman, she said that she did not pay enough attention to the situation of children upon return:

To be honest, especially when I see that my kids are suffering in school, as a mother, of course you rethink about return. Being a woman in this society is another issue ... but that is a personal issue. That was my choice, I decided to come back but my kids ... they had no choice.

Five interviewees said they would decide according to the evolving situation in Kurdistan, especially if the war with IS continued or if the economic situation deteriorated. For instance, the economic situation between the moment interviewees returned and when the interviews were conducted had changed drastically. Since 2014 the KRI has experienced one economic crisis after another, partially due to the budgetary cuts to the KRG by the Iraqi government, which might generate re-return from the region. Indeed, a total of 16 interviewees had either decided to leave or were thinking of re-returning. Four interviewees instead stated that they sometimes thought about the return, but at the moment of interviewing, they had not made any decision concerning it. When asked whether they regretted having returned, a little more than half either did (10) or had mixed feelings (4) about it. The rest did not regret their return (12).

My feelings are paradoxical. Sometimes I wish I did not come back, but another time I will say, coming here was much better than staying there.

So many things have changed in terms of construction, but people's minds are still old. 
The interviewees' accounts showed that there is a close relationship between transnationalism, on the one hand, and return intentions, decisions, post-return experiences and the possible rereturn, on the other hand (Carling and Erdal, 2014). A majority of the interviewees fostered attachments, travelled, or intended to travel, to the host countries on a regular basis. Only one interviewee talked about 'burning bridges'. One of the main reasons for the maintenance of transnational ties was the family members and friends abroad as well as established businesses in the host country. Also, the accumulated human and social capital from the host country was considered to enable a relatively risk-free re-return to the host society. Indeed, the challenges of reintegration can, in some cases, encourage the returnees to 'return' to the host society (King and Christou, 2014) or to opt for a transnational life arrangement between the host society and the homeland (Emanuelsson, 2008). Four interviewees suggested that re-return or circular return would be a preferred strategy in the current context (see Åkesson and Eriksson Baaz, 2015: 10). However, most saw KRG statements that aimed to attract return migrants to the region as a show of 'goodwill', since the realities were shadowed by corruption, nepotism and political instability. Returning with great aspirations and sometimes with expectations of a 'hero's welcome', returnees were re-evaluating their decisions.

Similarly to Iaria's (2014) study on Iraqi returnees, post-return transnationalism should not be considered as separate from pre-return transnationalism. Instead, the transnational livelihood strategies before return should be seen as a continuity of post-return strategies. This also applies to the decisions related to such strategies concerning return and re-return that need to be analyzed in relation to the socio-political context in which they take place. In this case, retaining a base in both countries prevailed as a preferred strategy. Citizenship in an EU country, United States or Canada enabled great mobility and facilitated the decision to return 
and to take the risk, similarly to Mortensen's (2014) findings, as well as to re-return to the host country if the return failed. Citizenship also facilitated the arrangement of transnational family life (see Emanuelsson, 2008) as, in most cases, the interviewees had left their family members in the host country to wait until they had settled securely in Kurdistan.

This study's findings show that interviewees' motivations to leave Kurdistan stemmed from a combined lack of political, social and economic security, and the return was motivated by increased security situation in the KRI. Regardless of positive host society experiences, they had decided to return to a Kurdistan that was undergoing an economic boom and intense nationbuilding processes, the latter still continuing strongly. This was also reflected in return motivations that were mostly nationalist/cultural, economic and family-related. Referring to their return as homecoming, the returnees wished to contribute to the development of the KRI. Social capital acquired in the host society, host country citizenship that provided increased mobility and transnational capital (networks, ties) facilitated the decision to return to the KRI. However, interviewees were at times lacking local forms of social capital to reintegrate and regardless of the symbolically significant 'diasporic homecoming', they experienced a mismatch between the expectations and realities stemming from nepotism, corruption and more traditional gender relations that became contrasted with positive host society experiences. The factors that had facilitated the return decision were also felt to provide a security network in the case of an eventual re-return, contemplated by a majority.

\section{Conclusion}

As Åkesson and Eriksson Baaz (2015: 1) underline, 'return is emerging as a key issue in the most recent policy documents on development in the European Union (EU) as well as in 
various member countries'. Other organizations such as the UNHCR also promote return migration as they see repatriation as a vital part of post-conflict reconstruction. As Sinatti (2015: 276) suggests, discussions on return migration actually parade as a triple-win scenario, where the sending states benefit from returning human capital and skills, host countries benefit from a temporary workforce and the returnees achieve better status in the homeland thanks to their migration experience. In the Iraqi Kurdish context, the issue has drawn significant attention from international organizations such as the IOM, state-linked actors and development aid agencies (e.g. in Finland, Norway, the Netherlands and so forth) that have also started investing in voluntary and assisted return programs for facilitating diaspora mobility towards the KRI (Emanuelsson, 2008; King, 2008). Although discursively, homeland political actors reference the Kurdish diaspora's contributions and call for the diaspora to 'return', few arrangements are put in place to facilitate diaspora interventions.

This study's broader aim was to map the field for policy-making and future studies on re-return dynamics and post-conflict reconstruction. The findings support the observation by Brinkerhoff (2012) that the homelands need to create an enabling environment for diasporas in order for them to contribute to the homeland's development and prosperity. Interviewees claimed that the institutional support they received was scarce, referring to the lack of KRGled policy in this matter. This study shows that returnees' experiences both preceding and following the return bear on their decision-making processes to stay in the 'homeland' or to opt for a re-return. On the basis of this study's findings, we suggest that reintegration measures in case of voluntary return need to better: 1) recognize the returnees' transnational human and social capital and knowhow and how that can be transformed into local forms of capital; 2) take the gendered and generational aspect of returnees' pre- and post-return experiences into account, the possible mismatch stemming from different gender relations, rule of law and 
institutional practices, and how that affects plans for re-return; and 3) acknowledge that even though diasporans might return for 'ethnic' or nationalist reasons, it does not automatically lead to sustainable and long-term return.

Voluntary returnees' transnational mobility and (family) life arrangements rarely fit into the classical understanding of return to homeland as a permanent condition. Therefore, reliable data are needed on the number of returnees, re-returnees and those, who have opted for circular migration to assess to what extent the current return of diaspora Kurds is sustainable. The more recent political developments, namely after the independence referendum, create new dynamics for engagement between the KRG and its diaspora. However, in case the voluntary return of highly skilled diaspora members does become sustainable, it will have a vital impact on post-conflict reconstruction and eventual state-building in the KRI. The social and human capital of returnees increases in importance in relation to the KRI's stability and survival in the midst of the on-going political conflicts and economic crises in the region.

\section{Notes}

\footnotetext{
${ }^{\mathrm{i}}$ Reliable data on the number of returnees, re-returnees or those, who have opted for circular migration to and from the KRI are lacking.

ii Cassarino (2004) distinguishes five theoretical paradigms to better understand return migration: the neoclassical approach; new economics of labour migration (NELM); structural approach; the transnational approach; and social network theory.

iii Fieldwork for this research has been funded by Coventry University (Pump-Prime Grant, 2016). Dr Bayar Dosky from the American University of Kurdistan assisted us in data collection and conducted the interviews in these three provinces.

iv The interviewees referred to 'integration' in relation to labor market participation, language learning and creation of social networks in host society.
} 


\section{References}

Åkesson L and Baaz ME (2015) Introduction. In: Åkesson L and Baaz ME (eds) Africa's return migrants: the new developers?. London: Zed Books Ltd, 1-23.

Aziz M (2011) The Kurds of Iraq: ethnonationalism and national identity in Iraqi Kurdistan. London: IB Tauris.

Bengio O (2012) The Kurds of Iraq: Building a State Within a State. Boulder, CO: Lynne Rienner Publishers.

Binder S and Tošić J (2005) Refugees as a particular form of transnational migrations and social transformations: Socioanthropological and gender aspects. Current Sociology 53(4): 607-624.

Bolognani M and Erdal MB (2017) Return imaginaries and political climate: Comparing thinking about return mobilities among Pakistani origin migrants and descendants in Norway and the UK. Journal of International Migration and Integration 18(1): 353-367.

Brah A (1996) Cartographies of Diaspora: Contesting Identities. New York: Routledge.

Brinkerhoff JM (2012) Creating an enabling environment for diasporas' participation in homeland development. International Migration 50(1): 75-95.

Carling J and Erdal MB (2014) Return migration and transnationalism: how are the two connected? International migration 52(6): 2-12.

Carling J and Pettersen SV (2014) Return migration intentions in the integrationtransnationalism matrix. International Migration 52(6): 13-30.

Carling J, Mortensen EB and Wu J (2011) A systematic bibliography on return migration, Oslo: PRIO.

Cassarino JP (2004) Theorising return migration: The conceptual approach to return Migrants revisited. IJMS: International Journal on Multicultural Societies 6(2): 253-279. 
Conway D, Potter RB, and St. Bernard G (2009) Repetitive visiting as a pre-return transnational strategy among youthful Trinidadian returnees. Mobilities 4(2): 249-273.

Crowcroft O (2014) Diaspora returns to build Iraq into next Dubai. The Guardian. 25 March, 14.

de Haas H (2005) International migration, remittances and development: myths and facts. Third World Quarterly 26(8): 1269-1284.

Di Saint Pierre F, Martinovic B and De Vroome T (2015) Return wishes of refugees in the Netherlands: The role of integration, host national identification and perceived discrimination. Journal of Ethnic and Migration Studies 41(11): 1836-1857.

Eastmond M (2006) Transnational returns and reconstruction in post-war Bosnia and Herzegovina. International Migration 44(3): 141-166.

Emanuelsson AC (2008) Transnational dynamics of return and the potential role of the Kurdish diaspora in developing the Kurdish region. Report. Defence Academy of the United Kingdom, Conflict Studies Research Centre.

Eriksson Baaz M (2015) Successive flops and occasional feats: development contributions and thorny social navigation among Congolese return migrants. In: Åkesson L and ErikssonBaaz M (eds), Africa's return migrants: the new developers?, London: Zed Books Ltd, 23-43.

Fehler BO (2011) (Re)constructing roots: Genetics and the 'return' of African Americans to Ghana. Mobilities 6(4): 585-600.

Fleischer A (2008) The role of the family for return migration, reintegration and re-emigration in Armenia. In: XXVII IUSSP International Population Conference, Busan, Korea, 2631 August 2013 
Fokkema T and Haas H (2015) Pre-and post-migration determinants of socio-cultural integration of African immigrants in Italy and Spain. International Migration 53(6): 326.

Gerhartz E (2010) When migrants travel back home: Changing identities in Northern Sri Lanka after the ceasefire of 2002. Mobilities 5(1): 147-165.

Grabska K (2015) Threatening mini-skirts: Returnee South Sudanese adolescent girls and social change. In: Åkesson L and Eriksson-Baaz M (eds) Africa's return migrants: the new developers?, London: Zed Books Ltd.

Hassanpour A and Mojab S (2005) Kurdish Diaspora. In: M Ember, Ember CL and Skoggard I (eds) Encyclopedia of Diasporas. Part I. Immigrant and Refugee Cultures around the World. Springer Science + Business Media, Inc., 214-224.

Ho ELE and Boyle M (2015) Migration-as-development repackaged? The globalizing imperative of the Singaporean state's diaspora strategies. Singapore Journal of Tropical Geography 36(2): 164-182.

Iaria V (2014) Post-Return transnationalism and the Iraqi displacement in Syria and Jordan. International Migration 52(6): 43-56.

Irwani M (2015) Clientelism and implementing social security programmes in post-conflict Iraqi Kurdistan region. New Castle upon Tyne: Cambridge Scholars Publishing.

Jain S (2013) For love and money: second-generation Indian-Americans 'return' to India. Ethnic and Racial Studies 36(5): 896-914.

Kaya Z and Whiting M (2017) Sowing division: Kurds in the Syrian war. Middle East Policy 24(1), 79-91.

King D (2008) Back from the 'outside': Returnees and diasporic imagining in Iraqi Kurdistan. International Journal on Multicultural Societies 10(2): 208-222. 
King R and Christou A (2011) Of counter-diaspora and reverse transnationalism: return mobilities to and from the ancestral homeland. Mobilities 6(4): 451-466.

King R and Christou A (2014) Second-generation 'return' to Greece: New dynamics of transnationalism and integration. International Migration 52(6): 85-99.

Kinsley, SF (1991) Whatever Happened to the Iraqi Kurds? News from Middle East Watch. Middle East Watch. < https://www.hrw.org/legacy/reports/1991/IRAQ913.htm>

Kunuroglu F, Yagmur K, Van De Vijver FJ and Kroon S (2017) Motives for Turkish return migration from Western Europe: home, sense of belonging, discrimination and transnationalism. Turkish Studies 1-29.

Leezenberg M (2005) Iraqi Kurdistan: Contours of a post-civil war society. Third World Quarterly 26(4): 631-647.

Long LD and Oxfeld E (2004) eds. Coming home?: refugees, migrants, and those who stayed behind. Pennsylvania: University of Pennsylvania Press.

Markowitz F and Stefansson AH (2004 eds) Homecomings: Unsettling paths of return. Maryland: Lexington Books.

Mhamad A (2015) The new wave of Kurdish migration. Your Middle East, 25 July 2015.

Mortensen EB (2014) Not just a personal decision. African Diaspora 7(1): 15-37.

Paasche E (2016a) The role of corruption in reintegration: Experiences of Iraqi Kurds upon return from Europe. Journal of Ethnic and Migration Studies 42(7): 1076-1093.

Paasche E (2016b) A conceptual and empirical critique of 'social remittances': Iraqi Kurdish migrants narrate resistance. In: Nowicka M and Serbedzija V (eds) Migration and social remittances in a global Europe. UK: Palgrave Macmillan, 121-141.

Saar M (2017) To return or not to return? The importance of identity negotiations for return migration. Social Identities 1-14. 
Sinatti G (2015) Return migration as a win-win-win scenario? Visions of return among Senegalese migrants, the state of origin and receiving countries. Ethnic and Racial Studies 38(2): 275-291.

Toivanen M (2014) Negotiating home and belonging. Young Kurds in Finland. Turku: Turku University Press.

Tsuda $\mathrm{T}$ (2009a) Why does the diaspora return home?. In: Tsuda $\mathrm{T}$ (ed) Diasporic homecomings: Ethnic return migration in comparative perspective. California: Stanford University Press, 21-43.

Tsuda T (2009b) Global inequities and diasporic return: Japanese American and Brazilian encounters with the ethnic homeland. In: Tsuda T (ed) Diasporic homecomings: Ethnic return migration in comparative perspective. California: Stanford University Press, 227259.

Tuomi J and Sarajärvi A (2009) Laadullinen tutkimus ja sisällönanalyysi. Helsinki: Tammi. van Bruinessen M (2000) Transnational aspects of the Kurdish question. Working paper, Florence: Robert Schuman Centre for Advanced Studies European University Institute. Van Houte M and Davids T (2008) Development and return migration: from policy panacea to migrant perspective sustainability. Third World Quarterly 29(7): 1411-1429.

Van Houte M (2014) Returnees for change? Afghan return migrants' identification with the conflict and their potential to be agents of change. Conflict, Security \& Development 14(5): 565-591.

Van Meeteren M, Engbersen G, Snel E and Faber M (2014) Understanding different postreturn experiences. Comparative Migration Studies 2(3): 335-360.

Voller Y (2014) The Kurdish liberation movement in Iraq: from insurgency to statehood. London: Routledge. 